Ann. Biol. anim. Bioch. Biophys., 1978, 18 (4), 977-984.

\title{
Precocious induction of oocyte maturation and ovulation in rainbow trout (Salmo gairdneri) : problems when using $17 \alpha$-hydroxy-20 $\beta$-dihydroprogesterone
}

\author{
par B. JALABERT, (1) B. BRETON, A. FOSTIER (1)
}

with the technical assistance of Pierrette REINAUD and Micheline HEYDORFF

Laboratoire de Physiologie des Poissons, I. N. R. A.

78350 Jouy en Josas, France

Summary. The efficiency of $17 \alpha$-hydroxy-20 $\beta$-dihydroprogesterone $(17 \quad \alpha-20 \quad \beta$ P $)$ administered alone or after pituitary priming, was investigated in vivo before peripheral migration of the germinal vesicle 4 to 8 weeks prior to natural ovulation. Treatmert with $17 \alpha-20 \beta \mathrm{P}$ alone (2 injections of $3 \mathrm{mg} / \mathrm{kg}$ at a 2-day interval) induced oocyte maturation in 94 p. 100 of the fish, but only 25 p. 100 ovulated. Treatment with $17 \alpha-20 \beta$ P $(3 \mathrm{mg} / \mathrm{kg}$ once) 2 days after pituitary priming $(1 \mathrm{ml} / \mathrm{kg}$ of trout pituitary extract, TPE, containing $3.25 \times 10^{-3} \mathrm{mg} / \mathrm{ml}$ of trout gonadotropin, $\mathrm{t}-\mathrm{GTH}$ ) induced maturation in all fish, $59 \mathrm{p} .100$ of which ovulated. In both cases, fish in which ovulation did not follow oocyte maturation were killed 15 days after the first injection ; ovarian follicles were either dissected by hand to remove mature oocytes, or incubated in vitro with prostaglandin $F_{2 \alpha}$ which induced successful ovulation. In all cases, oocytes obtained from in vivo ovulation, in vitro ovulation by $\mathrm{PGF}_{2 \alpha}$, or manual dissection were fertilized to some extent.

These observations demonstrate that:

1. Fertilizable mature oocytes can be produced 4 to 6 weeks in advance of natural spawning by injection of $17 \alpha-20 \beta P$ in vivo ;

2. Although ovulation can occur in vivo, or in vitro with $\mathrm{PGF}_{2 \alpha}$, the specific stimulus for ovulation is lacking in most of the fish injected with $17 \alpha-20 \beta P$ only, and appears to some extent when a pituitary priming is given prior to $17 \alpha-20 \beta \mathrm{P}$.

The possible involvement of gonadotropin in the synthesis and storage of some mediafor (or its precursor) specific for the induction of ovulation is discussed in relation to the plasma gonadotropin level in the different groups of females.

\section{Introduction.}

Previous work on rainbow trout (Jalabert et al., 1976) has already shown that $17 \alpha$-hydroxy-20 $\beta$-dihydroprogesterone (4 pregnen-17 $\alpha, 20 \beta$ diol-3 one ; abbreviation : $17 \alpha-20 \beta$ P) is able to induce normal oocyte maturation, i. e. resumption of meiosis characterized by clearing of the yolk and germinal vesicle breakdown (GVBD), and ovulation when injected to females presenting oocytes with the germinal vesicle

(1) Present address : Laboratoire de Physiologie des Poissons, I. N. R. A. Université de RennesBaulieu, BP 25 A, 35031 Rennes Cedex, France. 
(GV) in subperipheral position. But recent work in Coho salmon (Oncorhynchus kisutch) (Jalabert et al., 1978) and in northern pike (Exos lucius) (de Montalembert, Jalabert and Bry, 1978) has shown that injection of $17 \alpha-20 \beta$ P alone before GV peripheral migration results in oocyte maturation without ovulation. On the other hand, $17 \alpha-20 \beta \mathrm{P}$ is completely ineffective in carp (Cyprinus carpio) when administered alone, but induces successful maturation and ovulation in marginal temperature conditions when given after pituitary priming (Jalaberf et al., 1977).

The present experiment was undertaken in trout before peripheral migration of GV, 3 to 8 weeks in advance of expected natural ovulation. We tried to answer the following questions : - Does $17 \alpha-20 \beta P$ induce oocyte maturation without ovulation when injected at these precocious stages, as it does in Coho salmon and in pike? - What is the nature of the blockade between maturation and ovulation, if any? - Using a low dose of pituitary extract, what is the effect of preliminary pituitary priming on further $17 \alpha-20 \beta \mathrm{P}$ action?

\section{Material and methods.}

The experiment was carried out in December 1976 using 2-year old rainbow trout (Salmo gairdneri) weighing 400 to $600 \mathrm{~g}$ and kept in water of about $12^{\circ} \mathrm{C}$. Sixty-six females were chosen according to the state of maturity of a few oocytes; the criterium used was that the oocytes be 3.5 to $4.5 \mathrm{~mm}$ in diameter and without apparent GV at the periphery. They were squeezed out by abdominal stripping after anesthesia in a 0.5 p. 100 aqueous solution of 2-(phenoxy) ethanol (Merck). As seen in control fish without handling, the experimental fish would have ovulated naturally 3 to 8 weeks later. They were separated into 4 groups and submitted to different treatments (table 1) on day 0 (beginning of the experiment) and on day 2 ( 2 days later). The dose was injected intraperitoneally and calculated in order to always introduce the same volume of vehicle (physiological saline, $1 \mathrm{ml} / \mathrm{kg}$ ).

TABLE 1

Experimental treotments

\begin{tabular}{llll}
\hline & \multirow{2}{*}{$\begin{array}{c}\text { No. } \\
\text { of } \\
\text { fish }\end{array}$} & \multicolumn{2}{c}{ Treatments } \\
\cline { 3 - 4 } & 15 & Physiological saline & Physiological saline \\
\hline 1 & 17 & TPE $(0.5 \mathrm{mg} / \mathrm{kg})$ & Physiological saline \\
\hline 2 & 16 & $17 \alpha-20 \beta \mathrm{P}(3 \mathrm{mg} / \mathrm{kg})$ & $17 \alpha-20 \beta \mathrm{P}(3 \mathrm{mg} / \mathrm{kg})$ \\
\hline 3 & 17 & TPE $(0.5 \mathrm{mg} / \mathrm{kg})$ & $17 \alpha-20 \beta \mathrm{P}(3 \mathrm{mg} / \mathrm{kg})$ \\
\hline 4 & & & \\
\hline
\end{tabular}

$17 \alpha-20 \beta$ P : $17 \alpha$-hydroxy-20 $\beta$ dihydroprogesterone (4 pregnen-17 $\alpha$, $20 \beta$ diol-3 one).

TPE : Trout pituitary extract from dry acetonic powder. $0.5 \mathrm{mg} / \mathrm{kg}$ is equivalent to $3.25 \times 10^{-3} \mathrm{mg} / \mathrm{kg}$ of pure t-GTH measured by in vitro trout maturation assay. 
Trout pituitary extract (TPE) is a crude preparation made by homogenizing, in a glass-teflon homogenizer, acetone-dried trout pituitary powder suspended in physiological saline and taken from females at peripheral GV stage. The dose injected $\left(1 \mathrm{ml} / \mathrm{kg}\right.$ ) contains $3.25 \times 10^{-3} \mathrm{mg} / \mathrm{ml}$ of pure t-GTH (Breton, Jalabert and Reinaud, 1976), as measured by in vitro trout maturation assay (Jalabert, Breton, and Billard, 1974); it represents $1 / 10$ th of the dose known to induce maturation and ovulation in submature fish. Pure $17 \alpha-20 \beta$ P was prepared according to Fostier ef al. (1973).

Before each injection and at varied intervals until day 15 after the first injection, the fish were anesthetized and submitted to ovarian and blood sampling. Blood samples of $0.3 \mathrm{ml}$ were taken from a caudal vessel in the tail by puncture using a $1 \mathrm{ml}$ syringe previously rinsed with an heparine solution $(700 \mathrm{lU} / \mathrm{ml})$. The plasma obtained after centrifugation was kept frozen until subsequent determination of trout gonadotropin (t-GTH) by radioimmunoassay according to Breton and Billard (1977). When treatment resulted in oocyte maturation (characterized by GVBD) without ovulation, the fish were killed after 15 days and the ovaries removed. Mature oocytes were then either dissected out of the follicle using watchmaker's forceps to tear off the follicular envelope, or incubated in vitro within the follicle during $48 \mathrm{hrs}$. at $10^{\circ} \mathrm{C}$ in trout balanced salt solution (TBSS) (Jalabert, 1978) with or without prostaglandin $\mathrm{F}_{2 \alpha}\left(\mathrm{PGF}_{2 \alpha} 10^{-5} \mathrm{M}\right.$, Upjohn Co., Kalamazoo, Michigan) to induce ovulation.

Matured oocytes obtained after normal ovulation in vivo, manual dissection, or after ovulation in vitro by $\mathrm{PGF}_{2 \alpha}$ were inseminated with diluted sperm (1/100) according to Billard ef al. (1974) ; fertilizability was estimated from the proportion of eggs with apparently normal embryos after 10 days of development.
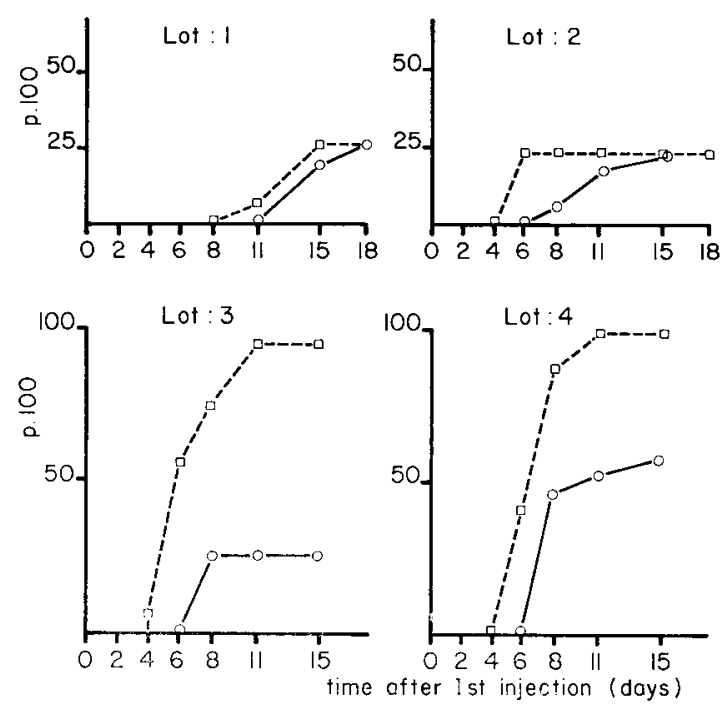

FIG. 1. - p. 100 fish exhibiting complete oocyte maturation (GVBD :

or complete ovulation (- - - ) in the 4 experimental groups.

Lot 1 , day 0 , day 2 : physiological saline.

Lot 2 , day $0:$ TPE $0.5 \mathrm{mg} / \mathrm{kg}$; day 2 : saline.

Lot 3, day 0 , day $2: 17 \alpha-20 \beta P 3 \mathrm{mg} / \mathrm{kg}$.

Lot 4, day $0:$ TPE $0.5 \mathrm{mg} / \mathrm{kg}$; day $2: 17 \alpha-20 \beta$ P $3 \mathrm{mg} / \mathrm{kg}$. 


\section{Results.}

Maturation and ovulation responses of fish in the different lots are shown on figure 1.27 p. 100 of control fish (lot 1) mature and ovulate after 15 to 18 days ; in lot 2 (TPE priming only), roughly the same proportion of animals mature and ovulate, but are slightly precocious. In both cases, ovulation always follows maturation. In lot 3 ( 2 injections of $17 \alpha-20 \beta$ P), apparently normal maturation occurs in all fishes within 6 to 11 days, but ovulation follows in only 25 p. 100 . When priming treatment with TPE is given before $17 \alpha-20 \beta P$ (lot 4), maturation still occurs in all fishes, but the proportion of those ovulating reaches 59 p. 100.

Plasma gonadotropin levels are presented in figure 2. In controls, basal levels are around $3.5 \mathrm{ng} / \mathrm{ml}$ at the beginning of the experiment and reach about $17 \mathrm{ng} / \mathrm{ml}$ in ovulating fish. In both lots 2 and 4, TPE priming injection induces a surge in plasma t-GTH up to $100 \mathrm{ng} / \mathrm{ml}$, followed by a slow decrease. In lot 3 (2 injections of $17 \alpha-20 \beta$ $P)$, there is a small rise in gonadotropin beginning on day 6 and reaching $12 \mathrm{ng} / \mathrm{ml}$ on day 15.

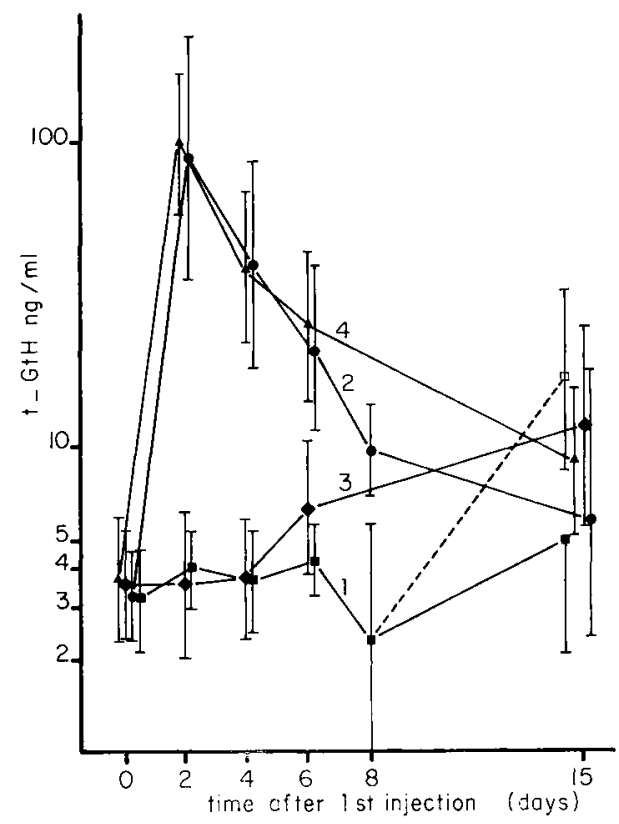

FIG. 2. - Mean plasma gonadotropin level (t-GTH) in the 4 experimental groups.

Vertical bars show the standard deviation.

Symbols for the different groups : $1:-$ - (non-maturing controls) or a ( 2 maturing and ovulating controls) ; $2:-\bullet-; 3:-\downarrow-; 4:-\wedge$.

Table 2 shows the results of incubation in vitro of follicles from fish exhibiting oocyte maturation without ovulation and killed on day 15 (lots 3 and 4). Even though some spontaneous ovulation occurs, PGF $_{2 \alpha}$ very significantly enhances the proportion of ovulation in vitro. 
TABLE 2

In vitro ovulation of follicles from fish exhibiting oocyfe maturation without ovulation (100 follicles per fish incubated for $48 \mathrm{hrs}$ at $10^{\circ} \mathrm{C}$ in TBSS with or without prostaglandin $\mathrm{PGF}_{2 \alpha}, 10^{-5} \mathrm{M}$ )

\begin{tabular}{|c|c|c|c|c|c|}
\hline \multirow{2}{*}{ Lot } & \multirow{2}{*}{ Treatment in vivo } & \multirow{2}{*}{$\begin{array}{c}\text { No. of } \\
\text { fish }\end{array}$} & \multicolumn{3}{|c|}{ Incubation of follicles in vitro } \\
\hline & & & Treatment & Mean p. 10 & ovulation \\
\hline \multirow{2}{*}{3} & \multirow{2}{*}{$17 \alpha-20 \beta \mathrm{P} / 17 \alpha-20 \beta \mathrm{P}$} & \multirow{2}{*}{7} & control & 8.5 & \\
\hline & & & $\mathrm{PGF}_{2 \alpha}$ & 77.4 & \\
\hline \multirow{2}{*}{4} & \multirow{2}{*}{ TPE $/ 17 \alpha-20 \beta P$} & \multirow{2}{*}{4} & control & 6.3 & \\
\hline & & & $\mathrm{PGF}_{\mathrm{a} \alpha}$ & 74.1 & \\
\hline
\end{tabular}

TABLE 3

Mean percent of embryonic development in eggs from in vivo ovulation (200 eggs per fish)

\begin{tabular}{|c|c|c|c|}
\hline Lot & Treatment & $\begin{array}{l}\text { Number } \\
\text { of fish }\end{array}$ & $\begin{array}{l}\text { Mean p. } 100 \text { of successful } \\
\text { embryonic development }\end{array}$ \\
\hline 1 & Phys. saline/Phys, saline & 4 & 80.4 \\
\hline 2 & TPE/Phys. saline & 4 & 93.2 \\
\hline 3 & $17 \alpha-20 \beta \mathrm{P} / 17 \alpha-20 \beta \mathrm{P}$ & 4 & 90.9 \\
\hline 4 & Phys. saline $/ 17 \alpha-20 \beta P$ & 10 & 87.5 \\
\hline
\end{tabular}

TABLE 4

p. 100 embryonic development in eggs inseminated either after manual dissection, or after in vitro ovulation by $\mathrm{PGF}_{2 \alpha}$

\begin{tabular}{|c|c|c|c|c|c|c|}
\hline \multirow[b]{2}{*}{ No. } & Lot & \multirow{2}{*}{$\begin{array}{l}\text { Fish } \\
\text { No. }\end{array}$} & \multicolumn{2}{|c|}{ Manual dissection } & \multicolumn{2}{|c|}{ Ovulation in vitro by $\mathrm{PGF}_{2 \alpha}$} \\
\hline & in vivo treatment & & $\begin{array}{l}\text { No. of } \\
\text { eggs }\end{array}$ & $\begin{array}{l}\text { P. } 100 \text { embryonic } \\
\text { development }\end{array}$ & $\begin{array}{l}\text { No. of } \\
\text { eggs }\end{array}$ & $\begin{array}{l}\text { P. } 100 \text { embryonic } \\
\text { development }\end{array}$ \\
\hline 3 & $17 \alpha-20 \beta P / 17 \alpha-20 \beta P$ & $\begin{array}{l}16 \\
21 \\
31 \\
36 \\
41 \\
66 \\
71 \\
74\end{array}$ & $\begin{array}{l}54 \\
53 \\
65 \\
23 \\
49 \\
55 \\
47 \\
50\end{array}$ & $\begin{array}{c}0 \\
75.5 \\
66.2 \\
0 \\
69.4 \\
43.6 \\
25.5 \\
0\end{array}$ & $\begin{array}{l}57 \\
20 \\
77 \\
48 \\
82 \\
79 \\
-78\end{array}$ & $\begin{array}{r}8.8 \\
33.3 \\
2.6 \\
4.4 \\
43.9 \\
5.1 \\
\overline{1.3}\end{array}$ \\
\hline 4 & TPE $/ 17 \alpha-20 \beta \mathrm{P}$ & $\begin{array}{l}03 \\
23 \\
63 \\
81\end{array}$ & $\begin{array}{l}49 \\
45 \\
52 \\
53\end{array}$ & $\begin{array}{r}10.2 \\
4.4 \\
21.2 \\
9.4\end{array}$ & $\begin{array}{l}82 \\
49 \\
85 \\
16\end{array}$ & $\begin{array}{c}20.7 \\
2.0 \\
0 \\
0\end{array}$ \\
\hline
\end{tabular}


Regarding fertilization data, eggs from in vivo ovulation (table 3) exhibit a normal amount of embryonic development without any significant difference between experimental and control groups. In eggs from matured but non-ovulated fish (table 4), inseminated after manual dissection or in vitro ovulation, the success of embryonic development is more irregular. Although a high percentage of development can be observed in the eggs of many fishes, particularly after manual dissection, eggs from some females give poor results and sometimes none. But comparison of data after manual dissection or after in vitro ovulation by $\mathrm{PGF}_{2 \alpha}$ shows that fertilization and development can occur in the eggs from any non-ovulated fish in groups 3 and 4 . This fact is shown in the particular case of fish No. 71 (table 4) in which 50 p. 100 of the oocytes were found to remain in an immature state, while the others were fully matured. The latter, dissected out of the follicle, exhibited 25.5 p. 100 development after insemination.

\section{Discussion.}

Induction of oocyte maturation without ovulation after injection of steroid hormones has already been observed in the amphibian Discoglossus pictus by AlonsoBedate ef al. (1971) and in various fishes : Misgurnus fossilis (Kirshenblat, 1952); northern pike (de Montalembert, Jalabert and Bry, 1978).

The present experiment using $17 \alpha-20 \beta \mathrm{P}$, which appears as the most likely mediator of oocyte maturation in trout (Jalabert, 1976), demonstrates that this steroid is also able to induce oocyte maturation well in advance of the natural process ( 3 to 8 weeks) and that these oocytes can be fertilized and develop normally until at least 10 days. However, this maturation is not necessarily followed by ovulation, in which case the mature oocytes to be inseminated must be removed from the follicular envelope by artificial means.

It must be underlined that the fishes chosen for the experiment were certainly heterogeneous as to expected time of natural spawning because of the absence of reliable criteria ; the follicle size only gives an approximation due to individual variations, and the non-peripheral position of the GV only indicates that natural maturation would normally occur more than 2 weeks later. This may explain why 25 p. 100 of the fish mature and also ovulate after treatment by $17 \alpha-20 \beta \mathrm{P}$ only, since this is the kind of response already found in females with oocytes at subperipheral GV stage (Jalabert ef al., 1976). Moreover, roughly the same proportion of fish ovulate at TPE priming only (lot 2), or spontaneously in controls after 15 to 18 days (lot 1). In fact, probably due to severe handling stress, these are in advance as compared with controls without such regular handling (anesthesia, blood and oocyle sampling). Thus, it can be assumed that a same proportion of fish in every group was advanced enough to mature and ovulate normally in response to $17 \alpha-20 \beta$ P. TPE priming or handling stress.

The rate of embryonic development is normally high in eggs from normally ovulated fish, whatever the treatment; this confirms that these females are probably closer to natural maturation, as discussed above. More surprising is the fact that embryonic development is always found in eggs of fish with mature but non-ovulated oocytes, some of them being probably very far from natural maturation. The discrepancy between data either after manual dissection or ovulation in vitro by PGF $_{2 \alpha}$ 
emphasizes that the conditions were not optimum in either case for taking mature oocytes out of their follicle. In addition, mature oocytes were kept in vivo in the follicle much longer than they normally would be after natural maturation in order to make sure that ovulation was really blocked before killing the fish ; thus, some aging could have occurred within the follicle. Despite these unfavorable conditions, it remains that some embryonic development was always found in the eggs from all experimental females after $17 \alpha-20 \beta$ P-induced maturation (lots 3 and 4 ). However, the success of embryonic development was evaluated by fixation in Stockard's solution as soon as 10 days after insemination, and it is not known if these embryos would have developed normally to hatching or further.

Another interesting point is that follicles containing mature oocytes, which do not ovulate spontaneously in vivo after in vivo $17 \alpha-20 \beta \mathrm{P}$ treatment, are able to contract and ovulate in vitro in response to $\mathrm{PGF}_{2 \alpha}$ as in naturally mature fish (Jalabert and Szöllösi, 1975). This implies that the lack of in vivo ovulation cannot be attributed to insufficient differentiation of the smooth muscle cells of the theca, but more probably to the absence of a specific mediator initiating follicle contraction, or of a precursor which should be synthesized and stored before $17 \alpha-20 \beta \mathrm{P}$ action. As preliminary priming with a low dose of TPE enhances the proportion of fish which ovulate in response to $17 \alpha-20 \beta P$ treatment, it can be hypothesized that gonadotropin t-GTH is the pituitary factor which, at low doses, favors the synthesis and storage of such an ovulation mediator. This hypothesis coincides with the fact that $17 \alpha-20 \beta P$ was able to induce maturation followed by successful ovulation when administered to fish at a later stage (subperipheral GV), characterized by plasma t-GTH levels of about 6 to $7 \mathrm{ng} / \mathrm{ml}$ (Jalabert et al., 1976) as compared to 3 to $5 \mathrm{ng} / \mathrm{ml}$ at the beginning of the present experiment.

Symposium sur la Reproduction des Poissons Paimpont, France, 19-21 septembre 1977.

Acknowledgments. - This work was parłly supported by the Ministère de l'Environnement ef de la Culture (Grant No. 37-76).

Résumé. L'efficacité de la $17 \alpha$-hydoxy-20 $\beta$ dihydroprogestérone $(17 \alpha-20 \beta$ P) seule ou après sensibilisation par un extrait hypophysaire a été testée chez des animaux dont le stade ovocytaire était antérieur à la migration périphérique de la vésicule germinative (V. G.) (4 à 8 semaines avant ovulation naturelle). Le traitement par la $17 \alpha-20 \beta$ P ( 2 injections de $3 \mathrm{mg} / \mathrm{kg}$ à 2 jours d'intervalle) a induit la maturation ovocytaire (reprise de la méiose caractérisée par l'éclaircissement du vitellus et l'éclatement de la V. G.) chez 94 p. 100 des poissons, dont 25 p. 100 seulement ovulèrent normalement. Le traitement par la $17 \alpha-20 \beta \mathrm{P}(3 \mathrm{mg} / \mathrm{kg})$ après sensibilisation hypophysaire (Extrait hypophysaire de Truite, $1 \mathrm{ml} / \mathrm{kg}$, contenant l'équivalent de $3,25 \times 10^{-3} \mathrm{mg} / \mathrm{ml}$ de gonadotropine de Truite, $\mathrm{t}-\mathrm{GtH}$ ) a induit la maturation ovocytaire chez tous les poissons, parmi lesquels $59 \mathrm{p} .100$ ovulèrent. Dans les deux cas, les poissons chez lesquels l'ovulation ne se produisit pas normalement après maturation furent sacrifiés 15 jours après la 1 re injection; les follicules ovariens furent soit disséqués pour extraction des ovules mûrs, soit incubés in vitro en présence de prostaglandine $\mathrm{PGF}_{2 \alpha}\left(1^{-5} \mathrm{M}\right)$ qui induisit l'ovulation avec succès. Les ovules mûrs récoltés après ovulation in vivo présentèrent une fécondabilité (estimée d'après le p. 100 de développements embryonnaires 10 jours après insémination) normalement élevée. Les ovules des animaux maturés mais non ovulés, récoltés après dissection manuelle ou ovulation in vitro, présentèrent une fécondabilité plus irrégulière, en fonction de la technique d'obtention, mais tous les animaux eurent des œufs fécondés. 
Ces observations démontrent que :

1. Des ovules mûrs fécondables peuvent être produits 4 à 8 semaines en avance sur la fraie naturelle par l'injection de $17 \alpha-20 \beta$ P.

2. Bien que l'ovulation puisse se produire (spontanément in vivo chez certains animaux, ou sous l'action de PGF $_{2 x}$ in vitro chez les autres), le stimulus spécifique de l'ovulation paraît faire défaut chez les poissons recevant la $17 \alpha-20 \beta$ P seule, et réapparaît dans une certaine mesure lorsqu'une injection de sensibilisation par un extrait hypophysaire est administré avant la $17 \alpha-20 \beta$ P.

L'implication possible de l'hormone gonadotrope $\mathrm{t}-\mathrm{G}+\mathrm{H}$ dans la synthèse ef le stockage d'un médiateur (ou d'un précurseur) spécifique de l'induction de l'ovulation est discutée, en liaison avec les niveaux de gonadotropine plasmatique dans les différents groupes de femelles.

\section{References}

ALONSO-BEDATE M., FRAILE A., LOPEZ-GORDO J. L., CALLE C., 1971. Action of progesterone on the maturation and ovulation of Discoglossus pictus (Amphibia anoura) : results obtained in vivo and in vitro. Acta. Embryol. exp., $\mathrm{n}^{\circ}$ hors série, 177-186.

BILLARD R., PETIT J., JALABERT B., SZÖLLÖSI D., 1974. Artificial insemination in trout using a sperm diluant 715-723. In BLAXTER J. H. S., Symp. on the early life history of fish, Springer Verlag, Berlin, Heideberg, N. Y.

BRETON B., BILLARD R., 1977 . Effects of photoperiod and temperature on plasma gonadotropin and spermatogenesis in the rainbow trout Salmo gairdneri Richardson. Ann. Biol. anim. Bioch. Biophys., 17, 331-340.

BRETON B., JALABERT B., REINAUD P., 1976. Purification of gonadotropin from rainbow trout (Salmo gairdneri Richardson) pituitary glands. Ann. Biol. onim. Bioch. Biophys., 16, 25-36.

FOSTIER A., JALABERT B., TERQUI M., 1973. Action prédominante d'un dérivé hydroxylé de la progestérone sur la maturation in vitro des ovocytes de la truite arc-en-ciel, Salmo gairdnerii. C. R. Acad. Sci. Paris, Série D, 277, 421-424.

JALABERT B., 1976. In vitro oocyte maturation and ovulation in rainbow trout (Salmo gairdneri), northern pike (Esox lucius) and goldfish (Carassius auratus). J. Fish. Res. Bd. Can., 33, 974-988.

JALABERT B., 1978. Production of fertilizable oocytes from follicles of rainbow trout (Salmo gairdneri) following in vitro maturation and ovulation. Ann. Biol. anim. Bioch. Biophys., 18, 461-470.

JALABERT B., BRETON B., BILLARD R., 1974. Dosage biologique des hormones gonadotropes de poisson par le test de maturation in vitro des ovocytes de truite. Ann. Biol. anim. Bioch. Bioph., 14, 217-228.

JALABERT B., BRETON B., BRZUSKA E., FOSTIER A., WIENIAWSKI J., 1977. A new tool for induced spawning : the use of $17 \alpha$-hydroxy-20 $\beta$-dihydroprogesterone to spawn carp at low temperature. Aquaculture, 10, 353-364.

JALABERT B., BRY C., BRETON B., CAMPBELL C., 1976. Action de la $17 \alpha$-hydroxy-20 $\beta$-dihydroprogestérone et de la progestérone sur la maturation ef l'ovulation in vivo ef sur le niveau d'hormone gonadotrope plasmatique t-GTH chez la truite Arc-en-Ciel (Salmo gairdneri). C. R. Acad. Sci. Paris, Série D, 283, 1205-1208.

JALABERT B., GOETZ F.W., BRETON B., FOSTIER A., DONALDSON E. M., 1978. Precocious induction of maturation and ovulation in Coho salmon Oncorhynchus kisutch. J. Fish. Res. Can. (in preparation).

JALABERT B., SZÖLLÖSI D., 1975. In vitro ovulation of trout oocytes effects of prostaglandins on smooth muscle-like cells of the theca. Prostaglandins, 9, 765-778.

KIRSHENBLAT E. D., 1952. The action of steroid hormones female vy'un. Dolk. Akad. Nauk. U.S. S. R., 83, 629-632.

MONTALEMBERT G. de, JALABERT B., BRY C., 1978. Problems with the precocious induction of maturation and ovulation in northern pike Esox lucius. Ann. Biol. onim. Bioch. Biophys., 18, 969-975. 